\title{
Customers' Perceptions as an Antecedent of Satisfaction with Online Retailing Services
}

\author{
Peter Misiani Mwencha* (Corresponding Author) \\ School of Business, Kenyatta University, \\ P.O. Box 53555-00200 Nairobi, Kenya \\ E-mail:mwencha@hotmail.com \\ Stephen Makau Muathe \\ School of Business, Kenyatta University, \\ P.O. Box 43844 - 00100 Nairobi, Kenya \\ E-mail: muathesm@yahoo.com
}

Received: 29 November 2017/ Revised: 21 January 2018/ Accepted: 31 January 2018/Published online: 24 April 2018

\begin{abstract}
The assessment of antecedents of customer satisfaction has become very important for the success of online retailing services. This paper reports the results of a study that investigated the antecedent role of customers' perceptions vis-a-vis satisfaction with online retailing services. While the study model conceptualizes customers' perceptions as a composite variable made up of three dimensions (perceived attributes, perceived risk and perceived value) prescribed by four established information systems (IS) and consumer behaviour frameworks, namely the Technology Acceptance Model (TAM), Perceived Risk Theory (PRT), Theory of Consumption Values (TCV) and Expectations-Artifact Model of Satisfaction (EAMS), it does not specify how the different perceptual factors influence online satisfaction; instead it aggregates all three dimensions into a higher-order construct called "customers' perceptions" and tries to understand the nature of relationship between the composite independent variable and the dependent variable. It employed a descriptive, correlational survey design whereby the response data collected from 240 registered users of 6 online retailers was analyzed using both descriptive as well as inferential statistics. The linear regression analyses indicate that the model provides a statistically significant explanation of the variation in consumers' online retailing satisfaction. The study also found empirical support for customers' perceptions as an antecedent of satisfaction with online retailing services.
\end{abstract}

JEL classification: M00, M31

Keywords: online retailing, customer satisfaction, perceptions, e-commerce, online consumer behaviour

\section{INTRODUCTION}

The commercial use of the internet has grown tremendously over the last two decades, characterized by a proliferation of various online-based electronic commerce (e-commerce) 
services. One of these services is online retailing (internet retailing, electronic retailing, or e-tailing), the direct sale from business to consumer (B-2-C) through electronic storefronts, typically designed around an electronic catalogue and shopping cart model (Stair \& Rynolds, 2010). Due to its huge popularity, online retailing has had a significant impact on several market segments such as travel, consumer electronics, hobby goods, and media goods across the globe (Weltevrenden \& Boschma, 2008). Consequently, online retailing has developed to become an established marketing channel in its own right within the consumer marketplace (Doherty \& Ellis-Chadwick, 2010).

In the context of online shopping, the website of an online retailer is the main contact point by which the online retailer and consumers interface in the online shopping process (Ahn, Ryu \& Han, 2004). Therefore, the quality of service rendered during the course of the whole online shopping transaction has significant influence on customer satisfaction (Ho \& Wu, 1999). While a high level of customer satisfaction does not necessarily guarantee customer loyalty, dissatisfaction will cause customers to take their business elsewhere. In other words, customers who are dissatisfied with the level of service they have received will be less likely to return in the future, or if they do return, they will most likely do so with less frequency than they did in the past. Conversely, customers who are extremely satisfied with their service experience with a given firm will most likely continue to return to that firm at the same frequency or even more frequently (Davis \& Heineke, 1998). As a result, electronic satisfaction (e-satisfaction) has become vital for online retailers to attract and retain online shoppers in this virtual environment (Ting, Ariff, Zakuan, Sulaiman \& Saman, 2016).

With the ever increasing popularity of electronic commerce, the evaluation of antecedents and of customer satisfaction has become very important for the online shopping store vendors as well as for researchers (Ho \& Wu, 1999). This is driven by the fact that customer satisfaction has become a hoped-for business outcome, and therefore focusing discussion on its antecedents is a necessary means to effect the desired outcome (Day \& Crask, 2000). However, a review of past research literature suggests that there are various antecedent factors of customer satisfaction, since the researchers chose the variables and factors that best suit each circumstance in their perception (Jiradilok, Malisuwan, Madan, and Sivaraks, 2014). In the online context, a number of studies have shown that satisfaction is mainly affected by customers' perceptions of their user experiences with information technology (IT) (Bhattacherjee, 2001a; 2001b). Therefore, in this study, satisfaction is conceptualized as an outcome of customers' perceived performance of the e-retailing service.

\section{LITERATURE REVIEW}

The literature review is drawn from past online consumer behaviour and information systems (IS) studies regarding two main variables: the independent variable - customer perceptions and the dependent variable - satisfaction. These variables are discussed in the following sections. The research hypothesis was developed based on theory from the combined literature.

\subsection{Customer Satisfaction}

Customer satisfaction is often defined as the customers' post-purchase comparison between pre-purchase expectation and performance received (Oliver, 1980; Zeithaml et al., 1993). Customer satisfaction is when products and services meet the expectation of the consumers (Kotler, Cunningham \& Turner, 2001). Like traditional business, online firms also need to satisfy their customers. Normally, most satisfied customers intend to re-purchase the products if the product performance meets their expectation. Moreover, from a marketing perspective, satisfaction 
ensures that customers develop positive emotions towards brands, while dissatisfaction translates into negative brand emotions (Pizam et al., 2016).

How one conceptualizes customer satisfaction also affects the modelling and measurement of the construct and its antecedents. Johnson et al. (1995) describe two basic conceptualizations of satisfaction, namely: transaction-specific and cumulative. Transaction-specific satisfaction is a customer's transient evaluation of a particular product or service experience (Cronin \& Taylor, 1992; Parasuraman et al., 1988). The cumulative model conceptualizes satisfaction as a cumulative construct that describes the total consumption experience with a product or service to date (Johnson and Fornell, 1991; Meeks, 1984; Van Raaij, 1981). Although transaction-specific satisfaction may provide insights into particular product or service encounters, cumulative satisfaction is arguably a better predictor of future behaviour (customer retention) and firm performance (profitability). The approach employed in this study is both aggregate and cumulative, in line with Johnson, Nader \& Fornell (1996). Accordingly, this study defined satisfaction as the customer's overall positive evaluation of the online retailing service following initial usage or based on all prior interactions/encounters and shopping experiences.

As demonstrated in past literature, customer satisfaction has been considered one of the most important concepts (McQuitty et al., 2000), and one of the main goals in marketing (Erevelles \& Leavitt, 1992). Owing to the growing importance of online commerce, a number of studies have focused on online satisfaction (Nusair \& Kandampully, 2008) because it helps to build customer trust (Flavian et al., 2006), enhances favourable word-of-mouth (Bhattacherjee, 2001), leads to repeat purchases (Kim, 2005), predicts purchase behaviour (McQuitty et al., 2000), projects the internet retailer's endurance and success (Evanschitzky et al., 2004) and is critical for retaining current users (Bhattacherjee, 2001a; 2001b). It is therefore imperative to be able to understand and measure satisfaction in the context of e-commerce.

According to Davis \& Heineke (1998), defining customer satisfaction in service operations has been approached in two general ways: (1) satisfaction as a function of disconfirmation; and (2) satisfaction as a function of perception. Owing to its complexity the disconfirmation model has been criticized by some researchers (Teas, 1994; Goode \& Moutinho, 1995) who prefer another approach. Consequently, the alternative approach that appears to be gaining acceptance is that satisfaction depends primarily on the customer's perception of service performance rather than on the disconfirmation between perception and expectation (Cronin \& Taylor, 1994; Teas, 1993). This approach is in line with extant research evidence which demonstrates that overall customer satisfaction in a service encounter is influenced by customers' perception (Brocato et al., 2012; Anderson et al., 2008; Sreejesh et al., 2017).

If customer satisfaction is viewed as an outcome, then focusing discussion on its antecedents is necessary to effect the desired outcome (Day \& Crask, 2000). This study will use this approach, whereby customers' perceptions are conceptualized as having an antecedent effect on satisfaction with online retailing services.

\subsection{Customers' Perceptions}

Perceptions are essentially mental maps made by people to give them a meaningful picture of the world on which they can base their decisions (Berelson \& Steiner, 1964). Perception occurs when stimuli are registered by one of the five human senses: vision, hearing, taste, smell and touch (Hoyer \& MacInni, 2008) via a process of sensing, selecting, and interpreting stimuli in the external, physical world into the internal, mental world (Wilkie, 1994). This perceptual process leads to a response which is either overt (actions) or covert (motivations, attitudes, and feelings) or both.

From a consumer behaviour perspective, perceptions are an attempt by a consumer to obtain and process information about a market situation with a purpose to make himself aware of the 
market and market offerings (Sahaf, 2008). Consumers establish and continuously update their perceptions about the alternative products/services that they are considering and based on those perceptions, they determine their attitudes towards the products (preferences). According to Schiffman \& Kanuk (2010), perception has strategy implications for marketers because consumers make decisions based on what they perceive rather than on the basis of objective reality. As a result, marketers have realized that understanding the perceptual process of consumers helps them to design better ways to help customers perceive their products and services favourably, especially since products and services that are perceived distinctly and favourably have a much better chance of being purchased than products or services with unclear or unfavourable images

Consequently, both marketing and information systems (IS) researchers have over the years sought to establish how perceptions of an IT innovation influence satisfaction (Lin \& Sun, 2009). It is therefore important that an online business understands the perceptions of the customer, as this can help the businesses to get a higher chance of satisfaction of their customers and at the same time attract and maintain their loyal customers (Yee \& Yazdanifard, 2014). Consequently, for this study, the customers' perceptions construct serves as the independent variable. It is composed of three constructs (perceived attributes, perceived risk and perceived value) identified in extant service management, consumer behaviour and technology adoption literature as playing an antecedent role via-a-vis satisfaction with online retailing services. However, in this study, the three dimensions are aggregated to form a composite higher-level construct known as "customers' perceptions" in order to investigate the relationship between the composite independent variable and the dependent variable. These variables are discussed in the following sections.

\subsubsection{Perceived Attributes}

Perceived attributes (PA) refer to the perception towards the primary characteristics of innovations by actual adopters and potential adopters. The behaviour of individuals is predicated by how they perceive these primary attributes. Because individuals might perceive primary characteristics in different ways, their eventual behaviours might differ (Moore \& Benbasat, 1991). PAs have been found to influence consumer usage patterns vis-à-vis information and communications technology (ICT), whereby users would perceive the attributes of these innovations favourably, while non-users and rejecters perceive them unfavourably enough not to use them (Rugimbana \& Iversen, 1994). In this study, PA is an aggregate variable of three dimensions (perceived usefulness, perceived compatibility and perceived ease of use) drawn from the work of Davis' TAM (1989), Rogers' IDT (1995; 2003), and Moore and Benbasat's PCI model (1991).

\subsubsection{Perceived Risk}

Perceived risk (PR) is a subjective concept that relates to the uncertainty and consequences associated with a consumer's action. A perception of risk with regard to purchasing or using a product or service dissuades a consumer from taking further action in that regard (Sharma, Durand \& Gur-Arie, 1981; Bhatnagar, Misra \& Rao, 2000). Due to the personal nature of such assessments, it cannot be objectively determined. PR can vary across individuals, situations and types of products and services (Day \& Crask, 2000). In the online retailing context, the intangible nature of online transactions poses a risk for consumers, impeding further use of online purchasing services (Bhatnagar et al., 2000; Hansen, 2007). Previous research on its antecedent role also suggests that PR negatively impacts internet shopping (Liebermann \& Stashevsky, 2002). By and large, perceived risk is conceptualized as a multi-dimensional construct in several information systems studies (Cox \& Rich, 1964; Jacoby \& Kaplan, 1972; Bettman, 1973; Bhatnagar et al., 2000, Forsythe \& Shi, 2003; Zhang, Tan, Xu \& Tan, 2012). This study adapted the perceived risk indicators from a review of relevant literature. These are i) financial risk (Jacoby \& Kaplan, 
1972; Bettman, 1973, Bhatnagar et al., 2000; Forsythe \& Shi, 2003), ii) performance risk (Jacoby \& Kaplan, 1972; Bettman, 1973; Forsythe \& Shi, 2003) and iii) personal/privacy risks drawn from work by Jarvenpaa \& Todd, 1997; Tan, 1999; Forsythe et al., 2006.

\subsubsection{Perceived Value}

Perceived value (PV) is a broad and abstract concept that refers to the benefits ascribed to the purchase/use of a product or service. As Monroe (1990) notes, value is "the trade-off between the quality or benefits [consumers] perceive in a product relative to the sacrifice they perceive by paying the price". Customer value is usually operationalized as a trade-off between quality (benefit) and cost (price) (Bolton \& Drew, 1991). Consumers sometimes attribute value to an item because its consumption or usage serves as a means to an end (Day \& Crask, 2000), or "value-in-use" (Woodruff \& Gardial, 1996). In knowing how to manipulate perceived value, the marketing manager in turn has knowledge essential to satisfying customers (Day \& Crask, 2000). The perceived value construct is multi-dimensional in nature (Sheth, Newman \& Gross, 1991; Sánchez-Fernández \& Iniesta-Bonillo, 2007). In this study, it has four dimensions drawn from relevant literature, namely i) monetary value, ii) convenience value, iii) social value and iv) emotional value. Online customer value can be different from its offline counterpart. In online retailing settings, not only the product itself, but also the web store and the internet channel contribute value to customers (Yunjie \& Shun, 2004). Previous research established that perceived customer value is a significant determinant of online transaction behaviour (Chew, Shingi \& Ahmad, 2006).

\section{THEORETICAL REVIEW}

This study is underpinned by four theories commonly used in services marketing and consumer technology adoption research. These are (i) Technology Acceptance Model, (ii) Perceived Risk Theory (iii) Theory of Consumption Values and (iv) Expectations-Artifact Model of Satisfaction.

\subsection{The Technology Acceptance Model}

The Technology Acceptance Model (TAM) of Davis (1989) and Davis, Bagozzi and Warshaw (1989) is one of the most widely used models of information systems (IS) for explaining or predicting the motivational factors in user acceptance of technology. The TAM states that users' positive perception of usefulness as well as perceived ease of use toward any technology will lead to a positive attitude toward using that particular technology, which in turn leads to the actual system use. In this study, the perceived usefulness (PU) and perceived ease of use (PEOU) indicators are drawn from the TAM. In spite of its efficacy, several researchers have sought to extend the TAM by adding different constructs. For instance, a study by Lin and Sun (2009) that investigated the link between TAM factors and e-satisfaction in the online shopping context found a positive and significant relationship between TAM factors and e-satisfaction. Alternatively, other studies have used the TAM in combination with other frameworks/models in various contexts to test its ability to predict different outcomes. For example, a study by Cho (upcoming) which focuses on consumer satisfaction in online shopping attempts to combine the expectations disconfirmation theory (EDT) with the TAM. Similarly, rather than predicting the acceptance and use of IS, this study investigated how TAM factors amalgamated with other consumer behaviour frameworks might contribute to online satisfaction. 


\subsection{The Perceived Risk Theory}

The Perceived Risk Theory was first introduced by Bauer (1960) in studying consumer behaviour. According to this theory, consumers perceive risk because they face uncertainty and potentially undesirable consequences as a result of purchase or usage of products/services. This means that the more risk consumers perceive, the less likely they will purchase/use a product or service (Bhatnagar, Misra \& Rao, 2000). The perceived risk construct in this study is derived from the perceived risk theory and adapted to the online retailing context. The core constructs of the theory have been decomposed by researchers into several perceived risk dimensions. For instance, Cunningham (1967) conceptualized six dimensions of perceived risk: performance, financial, opportunity/time, safety, social, and psychological risk, while Bhatnagar et al. (2000) argued that two types of risk exist when buying over the internet: product risk and financial risk. These risks are thought to be present in every choice situation but in varying degrees, depending upon the particular nature of the decision (Taylor, 1974). Moreover, different individuals have different levels of risk tolerance or aversion (Bhatnagar et al., 2000). Findings from a study by Forsythe and Shi (2003) which examined the relationship between types of risk perceived by internet shoppers and their online patronage behaviours suggested that perceived risk is a useful context to explain barriers to online shopping.

\subsection{Theory of Consumption Values}

The theory of consumption values (TCV) is a consumer behaviour theory that was developed by Sheth, Newman and Gross (1991a; 1991b). Over the years, TCV has evolved into a popular marketing theory and has been widely applied in various contexts, including IS. The theory focuses on explaining why consumers choose to use or not to use a specific product or service, arguing that consumer decisions are made based on perceived value. The TCV has five core constructs which are conceptualized as five different types of values (Functional value, Social value, Epistemic value, and Emotional value, and Conditional value) that underlie consumer choice behaviour. In this study, the perceived value construct is drawn from the TCV by Sheth et al. (1991a; 1991b) and adapted to the online retailing context. Kalafatis, Ledden and Mathioudakis (n.d.) postulate that all or any of the consumption values can influence a decision and can contribute additively and incrementally to choice; consumers weight the values differently in specific buying situations, and are usually willing to trade-off one value in order to obtain more of another. TCV's strong point is its analytical strength, which helps practitioners to understand consumer decision making. This enables them to develop practical strategies that address real market conditions (Gimpel, 2011).

\subsection{The Expectations-Artifact Model of Satisfaction}

The Expectations-Artifact Model of Satisfaction (EAMS) is a relatively new alternative framework that was first proposed by Johnson, Der and Fornell (1996) as a response to the shortcomings of extant satisfaction models such as the Disconfirmation Model by Oliver (1980) as well as the performance model. It posits that the primary determinant of customer satisfaction should be perceived performance. According to the model, expectations should have no positive or negative effect on satisfaction because they serve as neither an anchor, as in the performance model, nor a standard of comparison, as in the disconfirmation model, for evaluating satisfaction. At the same time, perceived performance should co-vary with customers' stated expectations. Performance gives rise to the expectations that customers report. Accordingly, the model posits a direct positive effect of perceived performance on satisfaction and a positive relationship between performance and expectations, without linking expectations directly to satisfaction, to capture these predictions (Johnson et al., 1996). 


\section{CONCEPTUAL FRAMEWORK}

The conceptual framework for this study is made up of various service marketing, consumer decision-making and IS constructs; it is based on the premise that customers' perceptions have a direct effect on satisfaction with online retailing services. This study attempts to develop a comprehensive model linking the factors drawn from the TAM model, the PRT, and the TCV to customers' satisfaction with online retailing services, which is drawn from the EAMS. However, the study does not specify how the different perceptual factors influence online satisfaction; instead it aggregates all factors into a composite variable - "customers' perceptions" - and posits the nature of relationships between the independent variables and the dependent variable. The conceptual framework, a graphical representation of how these theoretical constructs are interconnected, is depicted in Figure 1.

\section{Figure 1}

Conceptual Model

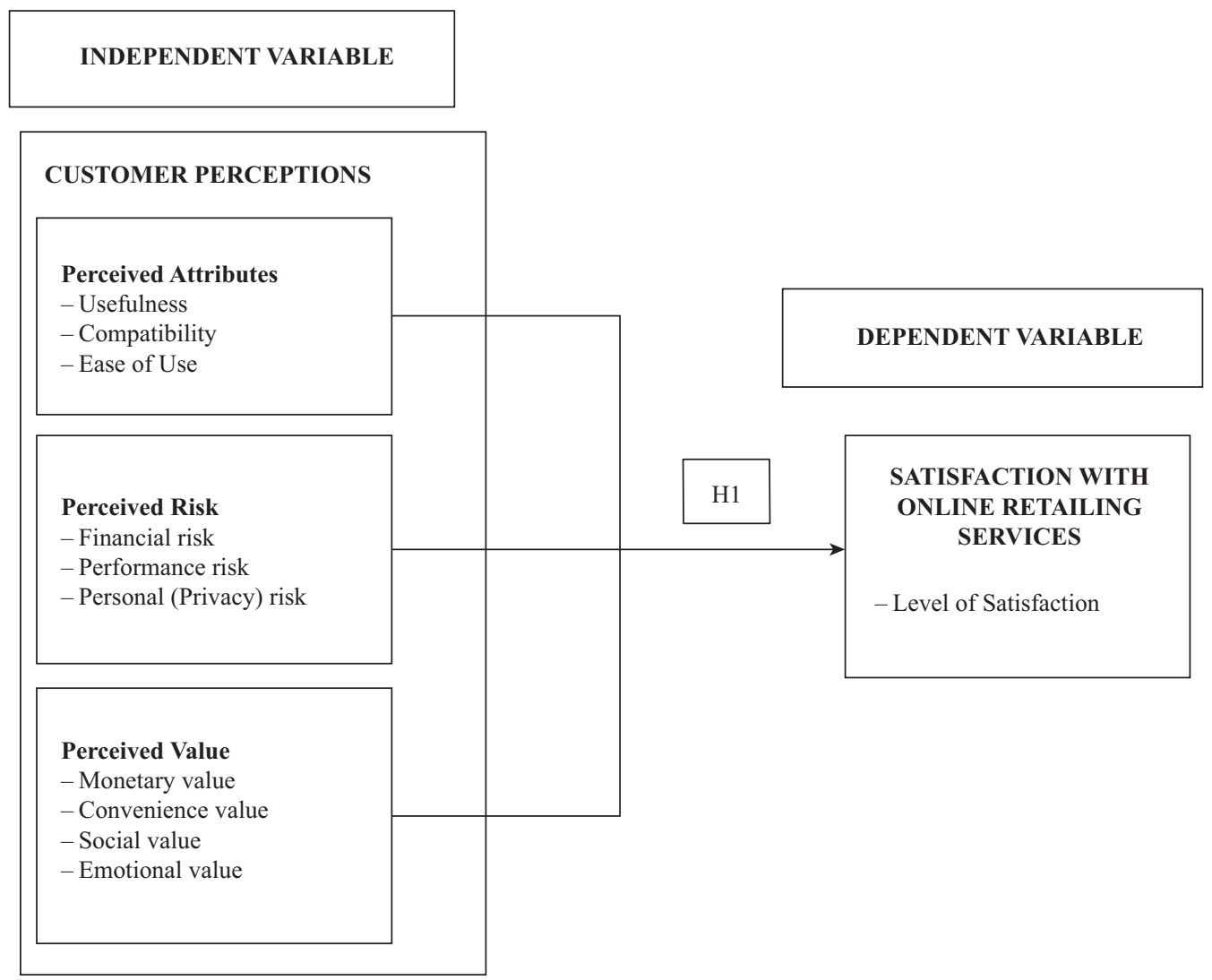

Source: Researcher, 2017.

\section{METHODOLOGY}

\subsection{Research Design}

This research adopted a cross-sectional, descriptive, correlational study design that sought to establish the antecedent role of customers' perceptions with regard to satisfaction with online retailing services in Kenya. Descriptive, correlational studies seek to investigate the studied phenomena but are not able to control or manipulate variables, and thus require the researcher to collect data and determine relationships without inferring causality (Swanson \& Holton, 2005). 


\subsection{Empirical Model}

The antecedent role of customers' perceptions in satisfaction was ascertained using a linear regression equation in line with Spencer et al. (2005). Since the customers' perception variable was computed as a continuous composite/aggregate value made up of three constructs (perceived attributes, perceived risk and perceived value), the study equation was in the form of a simple linear regression, a data analysis technique for identifying underlying correlations among data in research (Nimon, 2010). The simple linear regression (equation 1) is illustrated below:

$$
Y=\beta_{0}+\beta_{1} P_{1}+\varepsilon_{1}
$$

\section{Where:}

$Y=$ Customer Satisfaction (Dependent variable)

$\beta_{0}=$ Constant

$\beta_{1}=$ Linear regression coefficient

$P_{1}=$ Customers' Perceptions (Composite Value)

$\varepsilon_{1}=$ Error Term

\subsection{Sampling and Data Collection}

\subsubsection{Sampling}

The study respondents were 18,147 registered users drawn from six online retailing firms. A sample of 391 respondents was selected using multi-stage sampling methods including purposive, stratified and simple random sampling. Purposive sampling was employed to select the 6 online retailing firms that were accessible to the researcher. Thereafter, stratified random sampling, a probability sampling technique, was used to select the sample from the 18,147 respondents who were registered users of the online retailing services. Stratified random sampling was employed because the sampling frame was not homogeneous since the sample contained sub-groups, thereby necessitating a fair representation of these sub-groups in the sample size (Ahuja, 2005). This technique ensures that observations from all relevant strata are included in the sample (Lemm, 2010). Stratified sampling also guarantees that every possible sample matches the population distribution on strata-defining characteristics (Mallet, 2006).

To this end, proportional stratification technique was initially employed to arrange the study elements according to the respective strata. In proportional stratified sampling, the population is divided into groups or strata. Samples are then selected (e.g., using simple random sampling) by strata, in proportion to strata sizes (Mallet, 2006). The six online retailing firms in Nairobi, Kenya formed the six strata from which the respondents were drawn. Subsequently, a sample was randomly drawn from each strata and categories using random sampling method. In simple random sampling, every possible combination of population elements is equally likely to be selected (Mallet, 2006), thereby eliminating possible bias. For this study, a computerized random number generator was used to select the respondents out of the whole population. This was aimed at eliminating bias in the sample selection.

\subsubsection{Questionnaire Construction}

Primary data was collected using a 54-item questionnaire composed of three different sections (A, B \& C) based on different scales of measurement. Section A consisted of 3 questions on demographic factors, i.e. age, education level and income level; Section B had 46 close-ended Likert scale type questions with seven-point rating scale ranging from 1 = "strongly disagree" to 7 = "strongly agree"; Section C consisted of 5 close-ended questions with 5-point rating scale 
with various ordered responses ("strong yes" - "strong no"; "extremely well" - "extremely poorly"; "very dissatisfied" - "very satisfied"). The measures were adopted from previous studies (Swan et al., 1981; Oliver \& Westbrook, 1982; Oliver \& Bearden, 1983; Thompson et al., 1991; Compeau \& Higgins 1995b; Compeau et al. 1999, Sweeney \& Soutar, 2001; Venkatesh et al., 2003; Hernández et al., 2011) and reworded to suit the context of the current study. Each scale item was modelled as a reflective indicator of its hypothesized latent construct. A sample of the final questionnaire is shown in Appendix 1.

Table 1

Operationalization and Measurement of Study Variables

\begin{tabular}{|c|c|c|c|c|c|}
\hline Variable & Indicator & Nature & Operationalization & Measure & Question No. \\
\hline \multirow{3}{*}{$\begin{array}{l}\text { Perceived } \\
\text { Attributes }\end{array}$} & Usefulness & $\begin{array}{l}\text { Independent } \\
\text { Variable (IV) }\end{array}$ & $\begin{array}{l}\text { The degree to } \\
\text { which consumers } \\
\text { believe that usingan } \\
\text { e-commerce service } \\
\text { will enhance their } \\
\text { activities. }\end{array}$ & $\begin{array}{l}4 \text { items; } \\
7 \text { point Likert scale. } \\
\text { (Davis, 1989; } \\
\text { Davis et al., 1989) }\end{array}$ & B1-B4 \\
\hline & Compatibility & $\begin{array}{l}\text { Independent } \\
\text { Variable (IV) }\end{array}$ & $\begin{array}{l}\text { The degree to which } \\
\text { using an e-commerce } \\
\text { service is perceived } \\
\text { as being consistent } \\
\text { with the values, } \\
\text { needs, and habits of } \\
\text { potential user. }\end{array}$ & $\begin{array}{l}4 \text { items; } \\
7 \text { point Likert scale } \\
\text { (Moore \& Benbasat, } \\
\text { 1991) }\end{array}$ & B5-B8 \\
\hline & Ease-of-Use & $\begin{array}{l}\text { Independent } \\
\text { Variable (IV) }\end{array}$ & $\begin{array}{l}\text { The degree to which } \\
\text { an e-commerce } \\
\text { system is perceived } \\
\text { as relatively easy to } \\
\text { understand and use. }\end{array}$ & $\begin{array}{l}6 \text { items; } \\
7 \text { point Likert scale } \\
\text { (Davis, 1989; } \\
\text { Davis et al., 1989; } \\
\text { Forsythe et al., 2006) }\end{array}$ & B9-B14 \\
\hline \multirow{3}{*}{$\begin{array}{l}\text { Perceived } \\
\text { Risk }\end{array}$} & Financial risk & $\begin{array}{l}\text { Independent } \\
\text { Variable (IV) }\end{array}$ & $\begin{array}{l}\text { The degree of } \\
\text { anxiety regarding the } \\
\text { perceived financial } \\
\text { loss as a result of } \\
\text { e-commerce usage. }\end{array}$ & $\begin{array}{l}3 \text { items; } \\
7 \text { point Likert scale } \\
\text { (Zhang et al., 2012; } \\
\text { Forsythe et al., 2006) }\end{array}$ & B15-B17 \\
\hline & $\begin{array}{l}\text { Performance } \\
\text { risk }\end{array}$ & $\begin{array}{l}\text { Independent } \\
\text { Variable (IV) }\end{array}$ & $\begin{array}{l}\text { The level of } \\
\text { uncertainty regarding } \\
\text { the perceived } \\
\text { performance of an } \\
\text { e-commerce system. }\end{array}$ & $\begin{array}{l}5 \text { items; } \\
7 \text { point Likert scale } \\
\text { (Forsythe } \text { et al., 2006) }\end{array}$ & B18-B22 \\
\hline & Personal risk & $\begin{array}{l}\text { Independent } \\
\text { Variable (IV) }\end{array}$ & $\begin{array}{l}\text { The level } \\
\text { of anxiety regarding } \\
\text { the perceived } \\
\text { compromise/ } \\
\text { insecurity of personal } \\
\text { information } \\
\text { as a result of } \\
\text { e-commerce usage. }\end{array}$ & $\begin{array}{l}3 \text { items; } \\
7 \text { point Likert scale } \\
\text { (Forsythe et al., } \\
\text { 2006; Tan, 1999) }\end{array}$ & B23-B25 \\
\hline
\end{tabular}




\begin{tabular}{|c|c|c|c|c|c|}
\hline Variable & Indicator & Nature & Operationalization & Measure & Question No. \\
\hline \multirow{4}{*}{$\begin{array}{l}\text { Perceived } \\
\text { Value }\end{array}$} & $\begin{array}{l}\text { Monetary } \\
\text { value }\end{array}$ & $\begin{array}{l}\text { Independent } \\
\text { Variable (IV) }\end{array}$ & $\begin{array}{l}\text { The financial } \\
\text { utility derived from } \\
\text { e-commerce usage }\end{array}$ & $\begin{array}{l}4 \text { items; } \\
7 \text { point Likert scale } \\
\text { (Sweeney \& Soutar, } \\
2001)\end{array}$ & В26-B29 \\
\hline & $\begin{array}{l}\text { Convenience } \\
\text { value }\end{array}$ & $\begin{array}{l}\text { Independent } \\
\text { Variable (IV) }\end{array}$ & $\begin{array}{l}\text { The time, place } \\
\text { and execution utility } \\
\text { derived from usage } \\
\text { of the e-commerce } \\
\text { system }\end{array}$ & $\begin{array}{l}5 \text { items; } \\
7 \text { point Likert scale; } \\
\text { (Chang et al., 2012; } \\
\text { Mosavi \& Ghaedi, 2012) }\end{array}$ & B30-B34 \\
\hline & Social value & $\begin{array}{l}\text { Independent } \\
\text { Variable (IV) }\end{array}$ & $\begin{array}{l}\text { The perceived } \\
\text { favourability/ } \\
\text { approval derived } \\
\text { from one's social } \\
\text { milieu regarding } \\
\text { e-commerce usage }\end{array}$ & $\begin{array}{l}5 \text { items; } \\
7 \text { point Likert scale } \\
\text { (Tan, 1999; } \\
\text { Sweeney \& Soutar, 2001) }\end{array}$ & B35-B39 \\
\hline & $\begin{array}{l}\text { Emotional } \\
\text { value }\end{array}$ & $\begin{array}{l}\text { Independent } \\
\text { Variable (IV) }\end{array}$ & $\begin{array}{l}\text { The utility derived } \\
\text { from the feelings } \\
\text { or affective states } \\
\text { that an e-commerce } \\
\text { service generates }\end{array}$ & $\begin{array}{l}7 \text { items; } \\
7 \text { point Likert scale } \\
\text { (Thompson et al., 1991; } \\
\text { Compeau \& Higgins, } \\
\text { 1995b; Compeau et al., } \\
\text { 1999; Sweeney \& Soutar, } \\
\text { 2001) }\end{array}$ & B40-B46 \\
\hline $\begin{array}{l}\text { Customer } \\
\text { Satisfaction }\end{array}$ & $\begin{array}{l}\text { Level of } \\
\text { Satisfaction }\end{array}$ & $\begin{array}{l}\text { Dependent } \\
\text { Variable } \\
(\mathrm{MV})\end{array}$ & $\begin{array}{l}\text { The level } \\
\text { of satisfaction } \\
\text { with the e-commerce } \\
\text { system }\end{array}$ & $\begin{array}{l}4 \text { item, } 5 \text { point } \\
\text { Categorical scale } \\
\text { (Westbrook, 1980; } \\
\text { Oliver \& Bearden, 1983; } \\
\text { Oliver \& Westbrook, } \\
\text { 1982; Swan et al., 1981) } \\
\text { Ordinal }\end{array}$ & $\mathrm{C} 1-\mathrm{C} 5$ \\
\hline \multirow{3}{*}{$\begin{array}{l}\text { Demographic } \\
\text { Factors }\end{array}$} & Age & $\begin{array}{l}\text { Moderating } \\
\text { Variable } \\
(\mathrm{MV})\end{array}$ & Age group & $\begin{array}{l}1 \text { item; Ordinal } \\
\text { (Venkatesh et al., 2003) }\end{array}$ & A1. \\
\hline & Income & $\begin{array}{l}\text { Moderating } \\
\text { Variable } \\
(\mathrm{MV})\end{array}$ & Level of Income & $\begin{array}{l}1 \text { item; Ordinal } \\
\text { (Hernández, 2011) }\end{array}$ & A2. \\
\hline & Education & $\begin{array}{l}\text { Moderating } \\
\text { Variable } \\
\text { (MV) }\end{array}$ & Level of Education & 1 item; Ordinal & A3. \\
\hline
\end{tabular}

Source: Researcher (2017),

\subsubsection{Data Collection}

Primary data collection was carried out via an e-mail questionnaire that was administered to the 391 respondents. In order to increase the survey response rate (RR), the e-mail questionnaires were followed up with a self-administered questionnaire that was delivered to non-respondents using the drop-and-pick method as recommended in previous studies (Rojas-Méndez \& Davies, n.d., Ibeh et al., 2004), whereby respondents are contacted in person and asked to fill in a questionnaire at their most convenient time. Secondary data was collected from a variety of industry sources including newsletters, directories and trade publications as well as from industry magazines. 


\subsection{Validity and Reliability of Instrument}

\subsubsection{Validity}

Validity was assessed using two methods: criterion-related and content validity. Criterionrelated validity was demonstrated through the questionnaire items which were derived from measures validated in prior research (Nunnally \& Bernstein, 1994; Cooper \& Schindler, 2008) and standardized and adapted to the context of this study. Content validity was achieved using a panel of five experts in the field who were asked to give their views and suggestions on how to improve the questionnaire (Nunnally \& Bernstein, 1994; Cooper \& Schindler, 2008). The five experts evaluated the questionnaire and found that the questions were relevant to the study variables.

\subsubsection{Reliability}

Cronbach's Alpha coefficient $(\alpha)$ was used to assess reliability of the measures. As a rule of thumb, reliability of 0.7 and above is recommended to denote the research instrument as reliable (Roberts, Priest \& Traynor, 2006). Using this cut-off value, all but one of the measures exhibited internal consistency by having Cronbach's Alpha values greater than 0.7 with the exception of social value $(\alpha=0.538)$. However, Cronbach's Alpha for social value does meet the guidelines suggested by Hair, Anderson, Tatham and Black (2006), who recommended reliability level of 0.5 and above. Following the guideline developed Gliem \& Gliem (2003), low Cronbach's Alpha for social value could be an indicator of a poor scale (but still not unacceptable). This is not surprising since Cronbach's Alpha values are quite sensitive to the number of items in the scale. With short scales (e.g., scales with less than ten items) it is common to find quite low Cronbach values (e.g., .5).

Table 2

Reliability of instruments

\begin{tabular}{|c|c|c|c|}
\hline Factor & Measure & Number of Items & Reliability $(\alpha)$ \\
\hline \multirow{3}{*}{ Perceived Attributes (PA) } & Usefulness & 4 items (B1-B4) & 0.954 \\
\hline & Compatibility & 4 items (B5-B8) & 0.954 \\
\hline & Ease-of-Use & 4 items (B9-B14) & 0.950 \\
\hline \multirow{3}{*}{ Perceived Risk (PR) } & Financial Risk & 3 items (B15-B17) & 0.801 \\
\hline & Performance Risk & 5 items (B18-B22) & 0.702 \\
\hline & Personal Risk & 3 items (B23-B25) & 0.885 \\
\hline \multirow{4}{*}{ Perceived Value (PV) } & Monetary Value & 4 items (B26-B29) & 0.839 \\
\hline & Convenience Value & 5 items (B30-B34) & 0.954 \\
\hline & Social Value & 5 items (B35-B39) & 0.538 \\
\hline & Emotional Value & 7 items (B40-B46) & 0.975 \\
\hline Customer Satisfaction & Level of Satisfaction & 5 items $(\mathrm{C} 1-\mathrm{C} 5)$ & 0.941 \\
\hline
\end{tabular}

Source of data: Survey (2017).

\subsection{Data Analysis}

Data was analyzed using both descriptive as well as inferential statistics. Descriptive statistics provide a summary of the characteristics of response data (Wilson, 2006). The descriptive statistics that were used in this study include frequency distribution (in terms of counts and percentages) as well as measures of central tendencies (mean) and dispersion (standard deviation). On the other 
hand, inferential statistics was performed using binary linear regression. This is a type of analysis that examines the relationship between two variables drawn from the same sample population (Zickmund \& Babbin, 2007). Statistical Package for Social Sciences (SPSS) software version 19 was used to conduct the data analysis. Data was presented in the form of tables and narratives.

\section{RESULTS AND DISCUSSIONS}

The summary of the results is presented in two main sections: (1) descriptive statistics and (2) inferential statistics.

\subsection{Descriptive Statistics}

\subsubsection{Response Rates}

From three hundred and ninety-one (391) respondents who are registered as users of 6 online retailing services in Nairobi County, Kenya, two hundred and forty-two (240) were able to participate in the study by completing and returning the questionnaire on time. This was equivalent to a $61.38 \%$ response rate and is depicted in Table 3. According to Rubin and Babbie (2011), a 50\% response rate is considered adequate for reporting and analysis. This means that the response data was more than adequate for analysis.

\subsubsection{Demographic Characteristics}

This section shows the summarized responses regarding the demographic characteristics of the sample based on Section A of the questionnaire (Table 3) as well as the descriptive statistics for the composite indexes based on section B of the questionnaire (Table 4).

Table 3

Demographic characteristics of the sample $(n=240)$

\begin{tabular}{|c|c|c|c|}
\hline Variable & Category & Frequency & Percentage \\
\hline Age & $\begin{array}{l}\text { 18-23 Years } \\
24-29 \text { Years } \\
30-35 \text { Years } \\
36-41 \text { Years } \\
42-47 \text { Years } \\
48 \text { years and above } \\
\text { Total }\end{array}$ & $\begin{array}{r}30 \\
105 \\
77 \\
24 \\
4 \\
0 \\
240\end{array}$ & $\begin{array}{r}12.5 \\
43.8 \\
32.1 \\
10.0 \\
1.7 \\
0 \\
100.0\end{array}$ \\
\hline Level of Education & $\begin{array}{l}\text { High School Cert. } \\
\text { Diploma } \\
\text { Bachelor's Degree } \\
\text { Master's Degree } \\
\text { Doctorate } \\
\text { Professional } \\
\text { Other } \\
\text { Total }\end{array}$ & $\begin{array}{r}1 \\
37 \\
139 \\
51 \\
8 \\
3 \\
1 \\
240\end{array}$ & $\begin{array}{r}0.4 \\
15.4 \\
57.9 \\
21.3 \\
3.3 \\
1.3 \\
0.4 \\
100\end{array}$ \\
\hline Monthly Income & $\begin{array}{l}\text { Less than KSh24,999 } \\
\text { KSh25,000-49,999 } \\
\text { KSh50,000-74,999 } \\
\text { KSh75,000-99,999 } \\
\text { KSh100,000 - 124,999 } \\
\text { KSh125,000 \& above } \\
\text { Total }\end{array}$ & $\begin{array}{r}31 \\
45 \\
54 \\
43 \\
32 \\
35 \\
240\end{array}$ & $\begin{array}{r}12.9 \\
18.8 \\
22.5 \\
17.9 \\
13.3 \\
14.6 \\
100.0\end{array}$ \\
\hline
\end{tabular}

Source: Survey data (2017). 
In terms of the age of the response group $(n=240)$, the majority of respondents $(43.8 \%)$ were between $24-29$ years while the minority $(1.7 \%)$ were between $42-47$ years of age. None of respondents were older than 48 years of age. When it comes to education, the majority of the respondents $(57.9 \%)$ have a Bachelor's degree, followed by $51(21.3 \%)$ who have a Master's degree and $37(15.4 \%)$ who have a diploma. Only $1(0.4 \%)$ had a high school certificate, while $3(1.3 \%)$ had a professional qualification. With regard to the monthly income of the respondents, the majority (22.5\%) earned between KSh 50,000-74,999, whereas the minority $(12.9 \%)$ had a monthly income of less than KSh 24,999 per month. Taken as a whole, the demographic information showed that the respondents are predominantly young, relatively well educated and with relatively high levels of income. These findings concur with past studies regarding e-shoppers which established that online shoppers are generally younger, with a high level of income and a university education (Li, Kuo \& Russell, 1999; Vrechopoulos, Siomkos \& Doukidis, 2001; Dholakia \& Uusitalo, 2002).

In Table 4, the descriptive statistics for the ordinal data was presented as means and standard deviations.

Table 4

Descriptive statistics results for study constructs

\begin{tabular}{llc}
\multicolumn{1}{c}{ Variable } & \multicolumn{1}{c}{ Measure } & \multicolumn{1}{c}{ Statistic } \\
\hline Perceived Attributes & Mean & 4.3899 \\
\cline { 2 - 3 } Perceived Risk & Std. Deviation & 1.54140 \\
\hline Perceived Value & Mean & 4.1256 \\
\cline { 2 - 3 } & Std. Deviation & 1.27855 \\
Customer Perceptions & Mean & 4.2589 \\
\cline { 2 - 3 } & Std. Deviation & 1.16118 \\
Satisfaction & Mean & 4.2585 \\
\cline { 2 - 3 } & Std. Deviation & .62906 \\
\hline
\end{tabular}

$N=240$

Source: Survey data (2017).

The results indicate that perceived attribute had the highest mean score (4.389), closely followed by perceived value (4.258) and perceived risk (4.125). This high value concurs with several studies that have empirically established that the perceived attributes is a key element in usage behaviour as regards online services (Parthasarathy \& Bhattacherjee, 1998; Bhattacherjee, 2001b). The mean score of the customers' perception variable was also reasonably high (4.26), while the value of customer satisfaction was moderate (3.165). This moderate value could imply that users are not very pleased about their online shopping experience. This is a cause for concern since customers' overall satisfaction is an indication of how well customers like their experience with using the website, and it is probably the best indication of their willingness to return to the site again if they are to make another purchase in the category (Jiang \& Rosenbloom, 2005). With regard to the standard deviation, the value was 1.087 . 


\subsection{Inferential Statistics}

Further to the descriptive statistics, the researcher conducted a simple linear regression analysis so as to (i) examine whether the model provides a statistically significant explanation of the variation in the online retailing consumers' satisfaction, and more importantly to (ii) determine the empirical support for customers' perceptions as an antecedent of satisfaction with online retailing services. This section presents the findings and interpretation of the linear regression analysis.

\subsubsection{Normality Tests}

Before performing inferential statistics on the data, a diagnostic test was carried out to ascertain the normality of the customers' perceptions distribution. Normality was tested in order to determine whether parametric tests could be performed on the data as it is an important assumption of many statistical procedures such as t-tests, linear regression analysis, discriminant analysis and ANOVA (Razali \& Wa, 2011). This study used the formal normality test, specifically the 1-sample Kolmogorov-Smirnov (KS) test, to test for evidence of the normality of the customer perceptions distribution, in line with Razali and Wa (2011). The outcome of the test is shown in Table 5. According to the KS test, if the significance value is less than 0.05 , there is a significant difference between the population and sample, implying that the data is not normally distributed.

Table 5

Results of Kolmogorov-Smirnov normality test

\begin{tabular}{|c|c|}
\hline Predictor Variable & Significance Value \\
\hline Perceived Attributes & .000 \\
\hline Perceived Risk & .000 \\
\hline Perceived Value & .000 \\
\hline Customer Perceptions & .200 \\
\hline
\end{tabular}

Source: Survey data (2017).

The study results show that while the KS test values for the three predictors were 0.000 , the overall KS test p-value (.200) for the composite customer perceptions distribution was greater than the significance level ( $p=0.05$ ), thus implying that the customer perception variable data is normally distributed. This means that the customer perception distribution satisfies the assumptions of normality.

\subsubsection{Goodness of Fit}

Table 6 shows the output measures regarding the "goodness of fit", i.e. how well the model fits the data. The table presents the coefficient of determination (R-Square) which is used to test the goodness-of-fit of the model which reveals what percentage of variability in the dependent variable is accounted for by all of the independent variables.

Table 6

Model summary

\begin{tabular}{|c|c|c|c|c|}
\hline Model & R & R-Square & Adjusted R-Square & Std. Error of the Estimate \\
\hline 1 & 0.728 & 0.531 & 0.529 & 0.74603 \\
\hline
\end{tabular}

a. Predictors: (Constant), Customer Perceptions

Source: Research data (2017). 
If the R-Square value is 1 , then there is a perfect fit, whereas R-Square value 0 indicates that there is no relationship between the IV \& DV. According to Table 4, the adjusted R-Square value $=0.531$. This therefore means that there is a moderate relationship since the customers' perceptions variable accounts for $53.1 \%$ of the variation in the satisfaction variable, implying that other factors affecting satisfaction that were not studied in this research add up to 46.9.1\%. The adjusted $\mathrm{R}^{2}$ is important as it helps to discourage overfitting of the model (Doane \& Seward, 2011).

\subsubsection{ANOVA Results}

Table 7 reveals the SPSS output for the analysis of variance (ANOVA). The ANOVA table tells us whether or not the model can predict $Y$ using X. It contains the output for determining the statistical significance of the model.

Table 7

ANOVA

\begin{tabular}{|c|l|c|c|c|c|}
\hline Model & & Sum of Squares & df & F & Sig. \\
\hline \multirow{2}{*}{1} & Regression & 149.726 & 1 & 269.024 & 0.000 \\
\cline { 2 - 6 } & Residual & 132.460 & 238 & & \\
& Total & 282.186 & 239 & &
\end{tabular}

a. Predictors: Customer Perceptions

b. Dependent Variable: Satisfaction

Source: Research Data (2017).

The statistical significance of the model was assessed using the following hypotheses:

$\mathbf{H}_{0}: \beta 1=0$; i.e. Variation in $\mathrm{Y}$ is not explained by variation in $\mathrm{X}$

$\mathbf{H}_{1}: \beta 1 \neq 0$; i.e. Variation in $\mathrm{Y}$ is explained by variation in $\mathrm{X}$

According to the $\mathbf{H}_{\mathbf{0}}$, if a coefficient $(\beta i)=0$, then the distribution of the response variable $(\mathrm{Y})$ does not directly depend on the input variable $\mathrm{Xi}$, which can therefore be "dropped" from the model. Therefore, $\mathbf{H}_{\mathbf{0}}$ - the null hypothesis - implies that the model has no predictive value and $\mathbf{H}_{1}$ - the alternate hypothesis - implies that the model has predictive value. Since the significance value $(0.000)$ is less than 0.05 , the null hypothesis that the model is not useful was rejected, implying that the model is statistically significant and is therefore useful in predicting the relationship between customers' perceptions and satisfaction with online retailing services.

\subsubsection{Test of Hypothesis}

After establishing that the model is useful, the researcher tested the relative significance of the independent variable in predicting the dependent variable. Table 8 shows the linear regression coefficients with the output data.

Table 8

Coefficient table

\begin{tabular}{|c|c|c|c|c|}
\hline Variable & $\beta$ & Std. Error & $t=\beta / \mathrm{S} . \mathrm{E}$ & P-Value \\
\hline Constant & -2.193 & .330 & -6.642 & .000 \\
\hline Customer Perceptions & 1.258 & .077 & 16.402 & .000 \\
\hline
\end{tabular}

a. Dependent Variable: Satisfaction

Source: Survey data (2017). 
The hypothesis that was tested regarded the relationship between customers' perceptions and customer satisfaction with online retailing services.

$\mathrm{H}_{0}$ : There's no relationship between customers' perceptions and customer satisfaction with online retailing services.

As the study results in Table 8 show, the null hypothesis which proposes that customers' perceptions have no statistically significant effect on satisfaction with online retailing services was rejected since $\beta=1.258$ and $\mathrm{p}$-value $=0.000$. Consequently, the null hypothesis was rejected since $\beta \neq 0$ and $\mathrm{p}$-value $<\mathrm{a}$, meaning that customer perceptions have a statistically significant effect on customer satisfaction with online retailing services. This outcome lends support to the findings of Bolton and Drew (1994), who empirically established that customer perceptions have a significant positive relationship with customer satisfaction in the service context. This is in line with Sing (1991), who argued that customer satisfaction can be understood as a collection of multiple satisfactions with various objects that constitute the service system.

\section{FINAL CONSIDERATIONS}

\subsection{Conclusions}

The most important conclusion that can be drawn from the findings of this study is that customers' perceptions have an antecedent role with regard to satisfaction. In other words, the study concludes that customers' perceptions are associated with satisfaction with online retailing services.

\subsection{Implications of the Study}

The empirical findings of this study have implications for scholars, practitioners as well as policy makers.

\subsection{Theoretical Implications of the Study}

This study makes an important theoretical contribution to the study of online consumer behaviour by proposing and outlining perceptual antecedents of electronic consumer satisfaction. Moreover, by empirically testing the association between the two widely-used IS and consumer behaviour constructs, the study demonstrates that the proposed study model can be used to explain a significant amount of variance in customer satisfaction with e-retailing. The research also shows that customers' satisfaction with e-retailers depends on their perceptions vis-à-vis the website, confirming that online consumer behaviour is subject to individual perceptions. It therefore provides future scholars with a useful framework of how to incorporate both IS and consumer behaviour theories and constructs in their research projects.

\subsubsection{Practical Implications of the Study}

With the rapid growth of online retailing, customer satisfaction has become a major concern for online retailing managers and practitioners since customers are less likely to search for alternative purchase options when the current website offers satisfaction. The study therefore recommends that online retailing decision makers should put more effort in enhancing the quality of their services as a way of ensuring their customers are satisfied with their services. It is therefore imperative that online retailing firms have a good understanding of their target customers, since 
this will not only help in enhancing the desired levels of customer satisfaction, but will also help to increase customer loyalty towards their services in the long term.

\subsubsection{Policy Implications of the Study}

Due to its ever increasing popularity, online retailing has had a significant impact on several sectors including entertainment, consumer electronics, food and media goods, posing substantial challenges to consumers, industry players and regulators alike in the process. There is therefore a need for a regulatory framework that keeps online users safe while protecting the interest of all stakeholders, including the government. If need be, a quasi-independent multi-sectorial entity could be tasked with overseeing such a programme as is the case in other countries.

\subsection{Suggestions for Further Study}

Since the model conceptualizes customers' perceptions as a composite variable made up of perceived attributes, perceived risk and perceived value, it does not specify how the different perceptual factors influence online customer satisfaction; instead, it aggregates all factors into one construct called "customers' perceptions". Therefore, as a way of advancing and deepening our understanding of this link, future studies should consider investigating the specific nature of the relationships between perceived attributes, perceived risk and perceived value and electronic satisfaction. In addition, future studies might need to investigate other e-commerce sub-sectors/ context such as online travel reservation, e-entertainment as well as online education/e-learning amongst others for purposes of generalizing the research model.

The current research is one of few studies in the online retailing context that have attempted to examine the relationship between what customers perceive and online satisfaction. However, in spite of the fact that this current empirical study confirms that customer' perceptions are an important factor behind users' satisfaction in the online retailing context, it would be interesting to carry out qualitative, in-depth studies whereby online users detail their experience when shopping online. Such studies would give managers and practitioners deeper insight into what works and what does not insofar as online customer satisfaction is concerned, which will in turn contribute to reducing consumers' reluctance to purchase online.

\section{References}

Abadi, H.R.D., Hafshejani, S.N.A., \& Zadeh, F.K. (2011). Considering factors that affect users' online purchase intentions with using structural equation modeling. Interdisciplinary Journal of Contemporary Research in Business, 3(8), 463-471.

Adams, D.A., Nelson, R.R., \& Todd, P.A. (1992). Perceived usefulness, ease-of-use and usage of information technology: A replication. MIS Quarterly, 16(2), 227-247.

Ahn, T., Ryu, S., \& Han, I. (2004). The impact of the online \& offline features on the user acceptance of Internet shopping malls. Electronic Commerce Research \& Applications, 3(4), 405-420.

Ahuja, R. (2005). Research methods. New Delhi: Rawat Publications.

Anderson, S., Pearo, L.K., \& Widener, S.K. (2008). Drivers of service satisfaction linking customer satisfaction to the service concept and customer characteristics, Journal of Service Research, 10(4), 365-381.

Barnes, S.J., Bauer, H.H., Neumann, M.M., \& Huber, F. (2007). Segmenting cyberspace: A customer typology for the internet. European Journal of Marketing, 41(1/2), 71-93.

Bauer, R.A. (1960). Consumer behavior as risk-taking. In R.S. Hancock (Ed.), Dynamic Marketing for a Changing World (pp. 389-98). Chicago, IL: American Marketing Association,

Bearden, W.O. \& Teel, J. E. (1983). Selected determinants of consumers' satisfaction and complaint reports. Journal of Marketing Research, (XX), 21-28.

Berelson, B. \& Steiner, G.A. (1964). Human behaviour: An inventory of scientific findings. New York: Harcourt Brace Jovanovich. 
Bettman, J. (1973). Perceived risk and its components - A model and empirical test. Journal of Marketing Research, 10, 184-90.

Bhatnagar, A., Misra, S., \& Rao, H.R. (2000). Online risk, convenience and internet shopping behavior. Communications of the ACM, 42(11), 98-105.

Bhattacherjee, A. (2001a). Understanding information systems continuance: An expectation-confirmation model. MIS Quarterly, 25(3), 351-70.

Bhattacherjee, A. (2001b). An empirical analysis of the antecedents of electronic commerce service continuance. Decision Support Systems, 32(2), 201-214.

Bolton, R.N. \& Drew, J.H. (1994). Linking customer satisfaction to service operations and outcomes. In R.T. Rust \& R.L. Oliver (Eds.), Service quality: New directions in theory and practice (pp. 173 - 200). Newbury Park, CA: Sage Publications.

Boscheck, R. (1998). New media economics are transforming consumer relations. Long Range Planning, 31, 873-878.

Brocato, E.D., Voorhees, C.M., \& Baker, J. (2012). Understanding the influence of cues from other customers in the service experience: a scale development and validation. Journal of Retailing, 88(3), 384-398.

Burns, R.P. \& Burns, R. (2009). Business research methods and statistics using SPSS. London: Sage Publications.

Carifio, L. \& Perla, R. (2008). Resolving the 50 year debate around using and misusing Likert scales. Medical Education, 42, 1150-1152.

Chen, Q. \& Wells, W.D. (1999). Attitude toward the site. Journal of Advertising Research, September/October, 27-37.

Chew, K.-W., Shingi, P.M., \& Ahmad, M.I. (2006). TAM derived construct of perceived customer value and online purchase behavior: An empirical exploration. In R. Suomi, R. Cabral, J.F. Hampe, A. Heikkilä, J. Järveläinen \& E. Koskivaara (Eds.), Project e-society: Building bricks - 6th IFIP International Conference on e-Commerce, e-Business, and e-Government (13E 2006), October 11-13, 2006, 226 (pp. 215-227). IFIP Advances in Information and Communication Technology.

Cho, Y. (Upcoming). A consumer satisfaction model based on the integration of EDT and TAM: Comparative study of Korean and US consumers. Asia Pacific Journal of Marketing and Logistics, https://doi.org/10.1108/ APJML-07-2016-0127.

Choi, J.H. \& Jahng, J.J. (2009). Predictors of e-commerce use of the Internet: A multinational comparative study - the U.S., the Netherlands, and S. Korea. Seoul Journal of Business. 15(1), 65-90.

Churchill, G.A. \& Surprenant, C. (1982). An investigation into the determinant of customer satisfaction. Journal of Marketing Research, (XIX), 491-504.

Cox, D.F., \& Rich, S.U. (1964). Perceived risk and consumer decision making - the case of telephone shopping. Journal of Marketing Research, 1, 2-39.

Cronin, J.J. \& Taylor, S.A. (1992). Measuring service quality: A reexamination and extension. Journal of Marketing, $56,55-68$

Cronin, J.J. \& Taylor, S.A. (1994). SERVPERF versus SERVQUAL: Reconciling performance-based and performance-minus-expectations measurement of service quality. Journal of Marketing, 58(1), 125-131. doi10.2307/1252256.

Cunningham, S.M. (1967). The major dimensions of perceived risk. In D. Cox (Ed.), Risk taking and information handling in consumer behavior (pp. 82-109). Harvard: Harvard University Press.

Davis, F.D. (1989). Perceived usefulness, perceived ease of use, and user acceptance of information technology. MIS Quarterly, 13(3), 319-340.

Davis, F.D., Bagozzi, P.R., \& Warsaw, P. (1989). User acceptance of computer technology: A comparison of two theoretical models. Management Science, 35, 982-1003.

Davis, F.D. (1989). Perceived usefulness, perceived ease of use, and user acceptance of information technology. MIS Quarterly, 13(3), 319-339.

Davis, M.K. \& Heineke, J. (1998). How disconfirmation, perception and actual waiting times impact customer satisfaction. International Journal of Service Industry Management, 9(1), 64-73, https://doi. org/10.1108/09564239810199950

Day, E. \& Crask, M.R. (2000). Value assessment: The antecedent of customer satisfaction. Journal of Consumer Satisfaction, Dissatisfaction and Complaining Behaviour, 13, 52-60.

Dholakia, R. \& Uusitalo, O. (2002). Switching to electronic stores: Consumer characteristics and the perception of shopping benefits. International Journal of Retail and Distribution Management, 27(4), 154-165.

Doherty, N.F. \& Ellis-Chadwick, F. (2010). Internet retailing: The past, the present and the future. International Journal of Retail \& Distribution Management, 38(11/12), 943-965.

Erevelles, S. \& Leavitt, C. (1992), A comparison of current models of consumer satisfaction/dissatisfaction. Journal of Consumer Satisfaction, Dissatisfaction and Complaining Behavior, 5, 104-14.

Forsythe, S., Chuanlan, N., Shannon, D., \& Gardner, L.C. (2006), Development of a scale to measure the perceived benefits and risks of online shopping. Journal of Interactive Marketing, 20(2), 55-75. 
Forsythe, S.M. \& Shi, B. (2003). Consumer patronage and risk perceptions in internet shopping. Journal of Business Research, 56(11), 867-876.

Gimpel, G. (2011). Value-driven adoption and consumption of technology: Understanding technology decision making. Unpublished $\mathrm{PhD}$ thesis. Retrieved from: http://openarchive.cbs.dk/bitstream/handle/10398/8326/ Gregory\%20Gimpel.pdf? sequence=1 (August, 2012).

Gliem, J.A. \& Gliem, R.R. (2003). Calculating, interpreting, and reporting Cronbach's alpha reliability coefficient for Likert-type scales. Refereed Paper presented at the Midwest Research-to-Practice Conference in Adult, Continuing, and Community Education on October 8-10, 2003. The Ohio State University, Columbus, OH.

Hansen, T. (2007). Determinants of consumers' repeat online buying of groceries. The International Review of Retail, Distribution and Consumer Research, 16(1), 93-114.

Ho, C.-F. \& Wu, W.-H. (1999). Antecedents of customer satisfaction on the Internet: An empirical study of online shopping. Proceedings of the 32nd Hawaii International Conference on System Sciences - 1999. Retrieved from: http://www.ieee.org (13/11/2017).

Hoyer, W.D. \& MacInni, D.J. (2008). Consumer Behavior (5 ${ }^{\text {th }}$ Ed.). Mason, OH: South Western - Cengage Learning.

Jarvenpaa, S.L. \& Todd, P.A. (1996). Consumer reactions to electronic shopping on the world-wide web. International Journal of Electronic Commerce, 1(2), 59-88.

Jarvenpaa, S.L. \& Tractinsky, N. (1999). Consumer trust in an internet store: A cross-cultural validation. Journal of Computer-Mediated Communication, 5(2).

Jacoby, J. \& Kaplan, L. (1972). The components of perceived risk. In M. Venkatesan (Ed.), Proceedings, 3rd Annual Conference (pp. 383-393). Chicago, IL: Association for Consumer Research.

Jiang, P. \& Rosenbloom, B. (2005). Customer intention to return online: Price perception, attribute-level performance, and satisfaction unfolding over time. European Journal of Marketing, 39(1/2), 150-174.

Jiradilok, T., Malisuwan, S., Madan, N., \& Sivaraks, J. (2014). The impact of customer satisfaction on online purchasing: A case study analysis in Thailand. Journal of Economics, Business and Management, 2(1), 5-11.

Johnson, M.D. \& Fornell, C. (1991). A framework tot comparing customer satisfaction across individuals and product categories. Journal of Economic Psychology, 12, 267-286.

Johnson, M.D., Nader, G., \& Fornell, C. (1996). Expectations, perceived performance, and customer satisfaction for a complex service: The case of bank loans [Electronic version]. Retrieved from Cornell University, School of Hospitality Administration site: http://scholarship.sha.cornell.edu/articles/692 (15/11/2017).

Joines, J.L., Scherer, C.W., \& Scheufele, D.A. (2003). Exploring motivations for consumer web use and their implications for e-commerce. Journal of Consumer Marketing, 20(2), 90-108.

Kalafatis, S.P., Ledden, L., \& Mathioudakis, A. (n.d). Re-specification of the theory of consumption values. Retrieved from: http://eprints.kingston.ac.uk/18098/1/Kalafatis-S-18098.pdf (28/02/2014).

Kau, A.K., Tang, Y.E., \& Ghose, S. (2003). Typology of online shoppers. Journal of Consumer Marketing, 20(2/3), 139-154.

Kaye, B.K. \& Johnson, T.J. (2001). A Web for all reasons: uses and gratifications of Internet resources for political information. Paper presented at the Association for Education in Journalism and Mass Communication Annual Conference, Washington, DC, August.

Ko, H., Cho, C.-H., \& Roberts, M.S. (2005). Internet uses and gratifications. Journal of Advertising, 34(2), 57-70.

Korgaonkar, P.K. \& Wolin, L.D. (1999). A multivariate analysis of Web usage. Journal of Advertising Research, 39(2), 53-68.

Kotler, P., Cunningham, M.H., \& Turner, R.E. (2001). Marketing Management. Pearson Education.

Lee, D., Park, J., \& Ahn, J. (2000). On the explanation of factors affecting e-commerce adoption. Working Paper. Retrieved online from: http://misrc.umn.edu/workingpapers/fullpapers/2000/0025_120100.pdf. (23/09/2017).

Lemm, K. (2010). Stratified sampling. In N.J. Salkind (Ed.), Encyclopaedia of research design (pp. 1451-1454). Thousand Oaks, CA.: Sage Publications.

Liebermann, Y. \& Stashevsky, S. (2002). Perceived risks as barriers to internet and e-commerce usage. Qualitative Market Research: An International Journal, 5(4), 291-300.

Limayem, M., Hirt, S.G., \& Cheung, C.M.K. (2007). How habit limits the predictive power of intention: The case of information systems continuance. MIS Quarterly, 31(4), 705-37.

Liu, C. \& Forsythe, S. (2010). Post-adoption online shopping continuance. International Journal of Retail \& Distribution Management, 38(2), 97-114.

Luo, X. (2002). Uses and gratifications theory and e-consumer behaviors: A structural equation modeling study. Journal of Interactive Advertising, 2(2), 44-54.

Mallet, D. (2006). Sampling and Weighting. In R. Grover \& M. Vriens (Eds.), The handbook of marketing research (pp. 159-177). Thousand Oaks, CA: Sage.

McGuire, W.J. (1974). Psychological motives and communication gratification. In J.G. Blumler \& E. Katz (Eds.), The uses of mass communication. Beverly Hills, CA: Sage. 
McQuitty, S., Finn, A. \& Wiley, J. (2000), Systematically varying consumer satisfaction and its implications for product choice. Academy of Marketing Science Review. Retrieved from: www.amsreview.org/articles/ mcquity10-2000.pdf (June, 2016).

Meeks, J.G.T. (1984). Utility in economics: A survey of the literature. In: C.F. Turner \& M. Martin (Eds.), Surveying subjective phenomena (vol. 2, pp. 41-91). New York: Russell Sage Foundation.

Moore, G.C. \& Benbasat, I. (1991). Development of an instrument to measure the perceptions of adopting an information technology innovation. Information Systems Research, 2, 192-222.

Nimon, K. (2010). Regression commonality analysis: Demonstration of an SPSS solution. Multiple Linear Regression Viewpoints, 36(1), 10-17.

Nunnally, J.C. \& Bernstein, I.H. (1994). Psychometric theory. New York, NY: McGraw-Hill.

Nusair, K. \& Kandampully, J. (2008). The antecedents of customer satisfaction with online travel services: A conceptual model. European Business Review, 20(1), 4-19.

Oliver, R.L. (1980). A cognitive model of the antecedents and consequences of satisfaction judgments. Journal of Marketing Research, 17, 460-469.

Pallant, J. (2007). SPSS survival manual: A step by step guide to data analysis using SPSS for Windows (3rd Ed.). New York: McGraw Hill Open University Press.

Parasuraman, A., Zeithaml, V.A., \& Berry, L.L. (1988). SERVQUAL: A multiple-item scale for measuring consumer perceptions of service. Journal of Retailing, 64, 12-40.

Peng, D. W.-J. (2007). Factors affecting consumers' uses and gratifications of the Internet: A cross-cultural comparison among Taiwan, Hong Kong and China. International Journal of Computer Sciences and Network Security, $7(3), 233-242$.

Pizam, A., Shapoval, V., \& Ellis, T. (2016). Customer satisfaction and its measurement in hospitality enterprises: A revisit and update. International Journal of Contemporary Hospitality Management, 28(1), 2-35.

Rayburn, J.D. (1996). Uses and gratifications. In M.B. Salwen \& D.W. Stacks (Eds.), An integrated approach to communication theory and research (pp. 145-63). Mahwah, New Jersey: Lawrence Erlbaum.

Razali, N.M. \& Wah, Y.B. (2011). Power comparisons of Shapiro-Wilk, Kolmogorov-Smirnov, Lilliefors and Anderson-Darling Tests. Journal of Statistical Modelling and Analytics. 2(1), 21-33.

Rogers, E.M. (1995). Diffusion of innovations (4th Ed.). New York: The Free Press.

Rogers, E.M. (2003). Diffusion of innovations (5th Ed.). New York: The Free Press.

Roy, S.K. (2008). Determining uses and gratifications for Indian internet users. CS-BIGS, 2(2), 78-91. Retrieved online from: http:/www.bentley.edu/centers/sites/www.bentley.edu.centers/files/csbigs/roy.pdf (20/07/2016).

Rubin, A. \& Babbie, E.R. (2011). Research methods for social work (7th Ed). Belmonst, CA: Cengage Learning.

Rugimbana, R. \& Iversen, P. (1994). Perceived attributes of ATMs and their marketing implications. International Journal of Bank Marketing, 12(2), 30-35.

Sahaf, M.A. (2008). Strategic marketing: Making decisions for strategic advantage. New Delhi: Prentice Hall of India.

Severin, W.J. \& Taknard, W.J. (1997). Communication theories origins, methods, and uses in the mass media (4th ed.). White Plains, NY: Longman.

Sharma, S., Durand, R.M., \& Gurarie, O. (1981). Identification and analysis of moderator variables. Journal of Marketing Research, 18(3), 45-57.

Sheth, J.N., Newman, B.I., \& Gross, B.L. (1991a). Consumption values and market choices: Theory and applications. Cincinnati: South-Western Publishing Co.

Sheth, J.N., Newman, B.I., \& Gross, B.L. (1991b). Why we buy what we buy: A theory of consumption values. Journal of Business Research, 22(2), 159-170.

Schiffman, L.G. \& Kanuk, L.L. (2010). Consumer behavior: Global edition. London: Pearson Higher Education.

Spencer, S.J., Zanna, M.P., \& Fong, G.T. (2005). Establishing a causal chain: Why experiments are often more effective than mediational analysis in examining psychological processes. Journal of Personality and Social Psychology, 89, 845-851.

Sreejesh, S., Sarkar, J.G., Sarkar, A., Eshghi, A., \& Anusree, M. R. (2017). The impact of other customer perception on consumer-brand relationships. Journal of Service Theory and Practice, 2055-6225. https://doi.org/10.1108/ JSTP-11-2016-0207.

Swanson, R.A. \& Holton, E.F. III. (Eds.). (2005). Research in organizations: Foundations and methods of inquiry. San Francisco: Berrett-Koehler.

Taylor, J.W. (1974). The role of risk in consumer behavior. Journal of Marketing, 38(2), 54-60

Teas, R.K. (1993). Expectations, performance evaluation, and consumers' perceptions of quality. Journal of Marketing, 57(10), 18-34.

Ting, O.S., Ariff, M.S.M., Zakuan, N., Sulaiman, Z., \& Saman, M.Z.M. (2016). E-service quality, e-satisfaction and e-loyalty of online shoppers in business to consumer market; Evidence form Malaysia. Paper presented at the IOP Conference Series: Materials Science and Engineering.

Van Raaij, W.F. (1981). Economic psychology. Journal of Economic Psychology, 1, 1-24. 
Vrechopoulos, A., Siomkos, G., \& Doukidis, G. (2001). Internet shopping adoption by Greek consumers. European Journal of Innovation Management, 4(3), 142-152.

Warmbrod, J.R. (2014). Reporting and interpreting scores derived from Likert-type scales. Journal of Agricultural Education, 55(5), 30-47, doi: 10.5032/jae.2014.05030.

Weltevrenden, J.W.J. \& Boschma, R.A. (2008). Internet strategies and the performance of Dutch retailers. Journal of Retailing \& Consumer Services, 15, 163-178.

Wilkie, W.L. (1994). Consumer behavior. New York: Von Hoffman Press.

Wilson, A. (2006). Marketing research: An integrated approach (2 ${ }^{\text {nd }}$ Ed.). Gosport: Prentice Hall.

Woodruff, R.B. \& Gardial, S.F. (1996). Know your customer: New approaches to customer value and satisfaction. Cambridge, MA: Blackwell.

Yee, C.C. \& Yazdanifard, R. (2014). How customer perception shape buying online decision. Global Journal of Management and Business Research: E Marketing, 14(2), 1-9.

Yen, Y.S. (2011). The impact of perceived value on continued usage intention in social networking sites. Proceedings of the 2nd International Conference on Networking and Information Technology, 17, 217-223.

Yunjie, X. \& Shun, C. (2004). A conceptual model for customer value in e-commerce. Retrieved from: http://is2.lse. ac.uk/asp/aspecis/20040178.pdf (20/09/2016).

Zhang, L., Tan, W., Xu, Y., \& Tan, G. (2012), Dimensions of consumers' perceived risk and their influences on online consumers' purchasing behavior. Communications in Information Science and Management Engineering, 2(7), 8-14.

Zhou, L., Dai, L., \& Zhang, D. (2007). Online shopping acceptance model: A critical survey of consumer factors in online shopping. Journal of Electronic Commerce Research, 8(1), 41-62.

Zikmund, W.G \& Babin, B.J (2007) Exploring marketing research (9th Ed.). Ohio: Thomson South-Western. 


\section{APPENDIX}

\section{APPENDIX 1: QUESTIONNAIRE INSTRUMENT}

\section{SECTION A. CUSTOMER DEMOGRAPHIC FACTORS}

First things first: Tell us a bit about yourself. Please respond to each item by choosing the response that best describes you.

1. Age:

$\square 18-23$
$\square \quad 36-41$

2. Highest Level of Education:

$\square$ High School Certificate

$\square$ Masters Degree

$\square$ Other

3. Monthly income (gross):
$\square$ Below KSh 24,999
$\square$ KSh 50,000-74,999
$\square$ Ksh 100,000-KSh 124,999

\section{$24-29$}

$42-47$

Diploma

Doctorate

KSh 25,000-49,999

$\square$ KSh 75,000-99,999

$\square$ Ksh 125,000 \& above

\section{SECTION B. CUSTOMER PERCEPTION MEASURES}

Please indicate the extent to which you disagree or agree with each of the following statements by marking with a cross $(\mathrm{X})$ in the appropriate block provided. Please use the following seven-point rating scale ranging from $1=$ "strongly disagree" to $7=$ "strongly agree".

\section{CUSTOMER PERCEPTIONS}

Variable Label
Value Label

\begin{tabular}{l|l|l|l|l|l|l|l}
1 & 2 & 3 & 4 & 5 & 6 & 7
\end{tabular}

\section{Perceived Attributes}

1. The system enables me to accomplish what I want more quickly

2. The system makes me more effective

3. The system makes it easier to do what I want

4. I find the system useful

5. The e-commerce service fits my image well.

6. Using the system is compatible with all aspects of my lifestyle.

7. I think that using the system fits well with the way I like to do things.

8. Using the system fits into my lifestyle.

9. I find the system to be clear and understandable.

10. It's easy to get the system to do what I want it to do

11. It's easy to find what is being sought

12. The system has no hassles 


\section{CUSTOMER PERCEPTIONS}

\section{Variable Label}

13. Learning to operate the system is easy for me.

14. Overall, I believe that the system is easy to use.

\section{Perceived Risk}

15. This service costs more than conventional methods

16. I might be overcharged for using this service

17. I might not receive the product/service that I paid for

18. Inability to touch and feel the item worries me

19. One can't examine the actual product

20. It's not easy to get what I want

21. Information takes too long to come up/load

22. The e-commerce service failed to perform to my satisfaction

23. My credit card number may not be secure

24. My personal information may be sold to advertisers

25. My personal information may not be securely kept

\section{Perceived Value}

26. This e-commerce service is reasonably priced.

27. This e-commerce service is competitively priced

28. This e-commerce service offers value-for-money

29. Using this e-commerce service is economical

30. I can use this e-commerce service anytime

31. I can use this e-commerce service anyplace

32. This e-commerce service is convenient for me to use

33. I feel that the e-commerce service is convenient for me

34. I value the convenience of using this e-commerce service

35. This service would help me feel acceptable by others

36. This service would improve the way I am perceived

37. Using this service would make a good impression on others

38. My friends and relatives think more highly of me for using this service.

39. This service would give its user social approval

40. I enjoy using the system.

41. Some aspects of the system make me want to use it

42. I feel relaxed about using the system

43. Using the system makes me feel good

44. Using the system gives me pleasure

45. Using the system is fun

46. It's exciting to use the e-commerce service
Value Label

\begin{tabular}{l|l|l|l|l|l|l|}
1 & 2 & 3 & 4 & 5 & 6 & 7
\end{tabular}




\section{SECTION C. CUSTOMER SATISFACTION MEASURES}

Please indicate the extent to which you are satisfied with the e-commerce system by marking with a cross $(\mathrm{X})$ on one of the five blocks provided below the position which most closely reflects your satisfaction with the service.

1. How satisfied were you with the online retailing service initially?
$\square$ Very Dissatisfied
$\square$ Slightly Dissatisfied
Neither
$\square$ Somewhat Satisfied
$\square$ Very Satisfied

2. To what extent does this online retailer meet your needs?
$\square$ Extremely well
$\square$ Pleased
Satisfied
$\square$ Mixed
$\square$ Extremely poorly

3. My experience with this online retailer was very satisfactory
$\square$ Strong Yes
$\square$ Yes
Neutral
$\square$ No
$\square$ Strong No

4. Overall, I am with the service?
$\square$ Delighted
$\square$ Pleased
Satisfied
$\square$ Mixed
$\square$ Mostly Dissatisfied

5. If I could do it all over again, I would still use this service?
$\square$ Strong Yes
$\square$ No
$\square$ Yes
$\square$ Strong No

Thank you very much for your time. 